\title{
OPTIMALISASI POS PEMBINAAN TERPADU PENYAKIT TIDAK MENULAR DI DESA LOA KUMBAR, KECAMATAN SUNGAI KUNJANG, KOTA SAMARINDA, KALIMANTAN TIMUR
}

\section{Optimalization For Integrated Coaching Center of Non-Communicable Diseases in Loa Kumbar Village, District of Sungai Kunjang, City of Samarinda, East Kalimantan}

\author{
Swandari Paramita $^{1 *}$, Sjarif Ismail ${ }^{2}$, M. Khairul Nuryanto ${ }^{3}$, Trijono Patono Putro ${ }^{4}$ \\ ${ }^{1}$ Laboratorium Kedokteran Komunitas, Fakultas Kedokteran Universitas Mulawarman, Jl. Kerayan Kampus \\ Gunung Kelua, Samarinda 75119 \\ ${ }^{2}$ Pusat Penelitian Obat dan Kesehatan Masyarakat, Lembaga Penelitian dan Pengabdian Kepada Masyarakat \\ Universitas Mulawarman, Jl. Kerayan Kampus Gunung Kelua, Samarinda 75119 \\ ${ }^{3}$ Laboratorium Farmakologi, Fakultas Kedokteran Universitas Mulawarman, Jl. Kerayan Kampus Gunung \\ Kelua, Samarinda 75119 \\ ${ }^{3}$ UPTD Puskesmas Loa Bakung, Jl. Jakarta, Kecamatan Sungai Kunjang, Samarinda 75243 \\ *e-mail korespondensi: swandariparamita@gmail.com
}

\begin{abstract}
ABSTRAK
Masalah kesehatan masyarakat yang dihadapi saat ini adalah makin meningkatnya kasus PTM atau Penyakit Tidak Menular. PTM merupakan penyakit kronis, tidak ditularkan dari orang ke orang. PTM mempunyai durasi yang panjang dan umumnya berkembang lambat. PTM juga merupakan masalah utama di Samarinda, ibukota propinsi Kalimantan Timur. Walaupun berstatus ibukota propinsi, namun masih ada daerah yang terisolir selama puluhan tahun di Samarinda, yaitu Desa Loa Kumbar di Kecamatan Sungai Kunjang. Warga yang ingin menjangkau daerah lainnya untuk mendapatkan pelayanan kesehatan, harus menggunakan jalur sungai. Salah satu strategi dalam meningkatkan pembangunan kesehatan adalah pemberdayaan dan peningkatan peran masyarakat. Pos Pembinaan Terpadu (Posbindu) PTM merupakan peran serta masyarakat dalam melakukan kegiatan deteksi dini dan pemantauan faktor risiko PTM utama yang dilaksanakan secara terpadu, rutin, dan periodik. Hasil program yang telah dilakukan adalah mitra dalam hal ini pihak Puskesmas telah memulai pembentukan Posbindu PTM melalui sosialisasi program, serta melakukan pelaporan ke Dinas Kesehatan Kota Samarinda terkait kegiatan Posbindu PTM. Luaran pengabdian masyarakat yang telah tercapai adalah telah mulai dilakukan penerapan iptek kepada masyarakat, terutama penggunaan alat kesehatan untuk skrining faktor risiko penyakit tidak menular, khususnya tekanan darah tinggi dan kencing manis.
\end{abstract}

Kata Kunci: Pos Pembinaan Terpadu, Penyakit Tidak Menular, Loa Kumbar

\section{ABSTRACT}

The public health problem faced today is the increasing number of cases of NCD or Non-Communicable Diseases. NCD is a chronic disease, not transmitted from person to person. NCD has a long duration and generally develops slowly. NCD is also a major problem in Samarinda, the capital of the province of East Kalimantan. Despite being a provincial capital, there are still areas isolated for decades in Samarinda, namely Loa Kumbar Village in Sungai Kunjang District. Residents who want to reach other areas to get health services, must use the river transportation. One strategy in improving health development is empowerment and increasing the role of the community. Integrated Coaching Center of $N C D$ is the role of the community in conducting early detection and monitoring of the main NCD risk factors implemented in an integrated, routine and periodic manner. The program results that have been carried out are partners in this case the Puskesmas has started the establishment of Integrated Coaching Center of NCD through program socialization, as well as reporting to the Samarinda City Health Office regarding the activities of Integrated Coaching Center of NCD. The achievement of community service that has been achieved is the implementation of science and technology to the public, especially the use of medical devices to screen for risk factors for non-communicable diseases, especially high blood pressure and diabetes mellitus.

Keywords: Inetgrated Coaching Center, Non-Communicable Diseases, Loa Kumbar 


\section{PENDAHULUAN}

Kota Samarinda merupakan ibu kota propinsi Kalimantan Timur, dengan luas wilayah $718 \mathrm{~km} 2$. Kota Samarinda berbatasan dengan Kabupaten Kutai Kartanegara di sebelah utara, selatan, barat dan timur. Secara administratif, Kota Samarinda terdiri dari 10 kecamatan dan 59 desa atau kelurahan. Menurut data pada tahun 2015, penduduk Kota Samarinda mencapai 812.597 jiwa, dengan kepadatan penduduk $1.132 / \mathrm{km} 2$. Samarinda memiliki kondisi geografis daerah berbukit dan perairan sungai dengan ketinggian bervariasi dari 10 hingga 200 meter dari permukaan laut. Kota Samarinda beriklim tropis basah dengan hujan sepanjang tahun. Kota Samarinda dibelah oleh Sungai Mahakam dan menjadi gerbang menuju pedalaman Kalimantan Timur melalui jalur sungai, darat maupun udara (BPS, 2017).

Kecamatan Sungai Kunjang merupakan salah satu dari 10 kecamatan di wilayah Kota Samarinda. Kecamatan ini berbatasan dengan Kecamatan Samarinda Ulu di sebelah utara dan Kabupaten Kutai Kartanegara di sebelah selatan, barat dan timur. Kecamatan Sungai Kunjang memiliki luas wilayah 69,03 km2 yang mencakup 7 kelurahan, termasuk Kelurahan Loa Buah. Desa Loa Kumbar yang menjadi lokasi kegiatan pengabdian masyarakat ini termasuk dalam wilayah kerja Kelurahan Loa Buah. Kecamatan Sungai Kunjang, termasuk Kelurahan Loa Buah, dulunya merupakan wilayah yang banyak terdapat pabrik-pabrik pengolahan kayu lapis (plywood). Namun, sejak krisis moneter tahun 1998, pabrik-pabrik kayu lapis ini banyak yang tutup dan terjadi pengangguran massal pada tahun 1999. Hal ini pula yang terjadi di Desa Loa Kumbar (Pemkot Samarinda, 2017).
Walau berstatus ibukota Propinsi Kalimantan Timur, masih ada daerah yang masih terisolir selama puluhan tahun di Samarinda. Jalan darat Desa Loa Kumbar baru terbangun pada akhir tahun 2014 lalu. Sebelum itu, warga yang ingin menjangkau daerah lainnya untuk bersekolah atau mendapatkan pelayanan kesehatan, masih menggunakan jalur Sungai Mahakam (Pardede, 2015). Informasi dari Dinas Bina Marga dan Pengairan Pemerintah Kota Samarinda, meskipun pembukaan akses jalan sudah rampung, namun para pengemudi harus ekstra hati-hati dikarenakan hanya sebagian jalan sepanjang 750 meter di sisi Desa Loa Kumbar yang sudah dicor beton. Pantauan badan jalan terdiri dari pembukaan lahan baru dan jalur angkutan batubara. Beberapa titik tanjakan masih begitu tajam dan masih seluruhnya terbuat dari tanah (Pardede, 2014). Saat ini di pertengahan tahun 2017, dengan kondisi cuaca di Kota Samarinda yang memasuki musim penghujan, jalan menuju Desa Loa Kumbar terputus dan tidak dapat dilalui kendaraan bermotor sama sekali.

Selain kondisi Desa Loa Kumbar yang terisolir tidak dapat dijangkau dengan jalan darat dan hanya bisa melalui jalan sungai, pemukiman ini belum terlayani air bersih dan masih minim infrastruktur lain. Untuk sumber listrik, Desa Loa Kumbar mengandalkan genset pemberian dari DPRD Kota Samarinda berkapasitas 20 $\mathrm{kVA}$, yang hanya bisa dinyalakan hingga pukul 12 malam. Pemakaian listrik tiap rumah pun dibatasi, hanya 450 watt untuk menyalakan lampu dan televisi sebagai hiburan (Pitakasari, 2011). Sejak akhir tahun 2017 jaringan PLN akhirnya masuk ke desa Loa Kumbar, dengan demikian penggunaan genset sudah tidak dipakai lagi. 
Desa Loa Kumbar hanya terdiri dari satu rukun tetangga, yaitu RT 19. Saat ini memiliki jumlah penduduk 87 kepala keluarga (KK) atau sekitar 300 orang, yang menempati sekitar 70 rumah. Kampung ini identik dengan masyarakat yang mayoritas bekerja sebagai petani pisang. Mereka memiliki lahan kebun pisang di belakang kampung yang jalan aksesnya melewati pabrik bekas kayu lapis PT Wahana Rimba Kencana, yang saat ini telah tutup akibat krisis moneter tahun 1998 yang lalu (Ernawati, 2016).

Untuk pelayanan masalah kesehatan, Desa Loa Kumbar termasuk dalam wilayah kerja Puskesmas Loa Bakung. Data dari puskesmas menunjukkan ada Posyandu Kalamur di Desa Loa Kumbar, dengan jumlah kader sebanyak 3 orang. Posyandu ini termasuk posyandu pratama. Setiap bulan dijadwalkan rutin oleh Puskesmas Loa Bakung mengadakan kegiatan Puskesmas Keliling ke Desa Loa Kumbar. Bentuk kunjungan selain melaksanakan kegiatan posyandu disana, juga melakukan kegiatan pengobatan masyarakat Desa Loa Kumbar. Setiap kegiatan Puskesmas Keliling dilaksanakan di Desa Loa Kumbar, tim dari puskesmas yang berangkat cukup lengkap, dengan membawa tenaga dokter, bidan, perawat dan apoteker, serta membawa obat-obatan untuk mengobati masyarakat desa yang sakit. Dengan terputusnya jalan darat menuju Desa Loa Kumbar, sejak setahun terakhir ini kegiatan Puskesmas Keliling terpaksa menggunakan jalur sungai menggunakan perahu. Pengadaan perahu dilakukan oleh pihak Kecamatan Sungai Kunjang, dengan menyewa perahu milik warga setempat (Puskesmas Loa Bakung, 2016).

Masalah kesehatan di Desa Loa Kumbar tidak jauh berbeda dengan masalah kesehatan yang tercatat di induk Puskesmas Loa Bakung, dan tidak jauh berbeda dengan masalah kesehatan di tingkat Dinas Kesehatan Kota Samarinda. Bersama dengan penyakit menular seperti ISPA dan diare, Penyakit Tidak Menular (PTM) juga menduduki peringkat atas untuk penyakit yang paling sering ditemukan pada warga disana, terutama mereka yang berusia dewasa. PTM yang paling sering ditemukan adalah hipertensi dan diabetes. Selain itu masalah PTM yang juga ditemukan di Desa Loa Kumbar adalah penyakit sendi atau rematik (Puskesmas Loa Bakung, 2016).

Data Dinas Kesehatan Propinsi Kalimantan Timur menunjukkan bahwa prevalensi hipertensi di Kalimantan Timur menduduki peringkat ketiga di Indonesia (29,6\%) setelah Bangka Belitung (30,9\%) dan Kalimantan Selatan (30,8\%). Prevalensi hipertensi di Indonesia sendiri sebesar 25,8\%. Sementara itu prevalensi diabetes di Kalimantan Timur menduduki peringkat keempat di Indonesia (2,3\%), setelah DI Yogyakarta (2,6\%), DKI Jakarta (2,5\%), dan Sulawesi Utara (2,4\%). Prevalensi diabetes di Indonesia sendiri sebesar $1,5 \%$ (Kemenkes RI, 2013).

Desa Loa Kumbar merupakan daerah terisolir, meskipun lokasinya berada di wilayah ibukota propinsi Kalimantan Timur. Dengan terputusnya jalan darat menuju ke desa tersebut, maka untuk menuju Desa Loa Kumbar hanya bisa dilakukan melalui jalur sungai. Selain penyakit menular seperti ISPA dan diare, permasalahan kesehatan pada penduduk dewasa di Desa Loa Kumbar juga mencakup PTM, seperti hipertensi, diabetes dan penyakit sendi atau rematik. Gambar 1 menunjukkan posisi geografis Desa Loa Kumbar yang berada di paling 
ujung dan saat ini hanya bisa diakses lewat jalur sungai, seperti yang terlihat pada Gambar 2. Daerah yang berwarna merah merupakan wilayah Kelurahan Loa Buah, Kecamatan Sungai Kunjang. Gambar 3 hingga Gambar 6 menunjukkan akses menuju Desa Loa Kumbar yang hanya bisa lewat sungai.
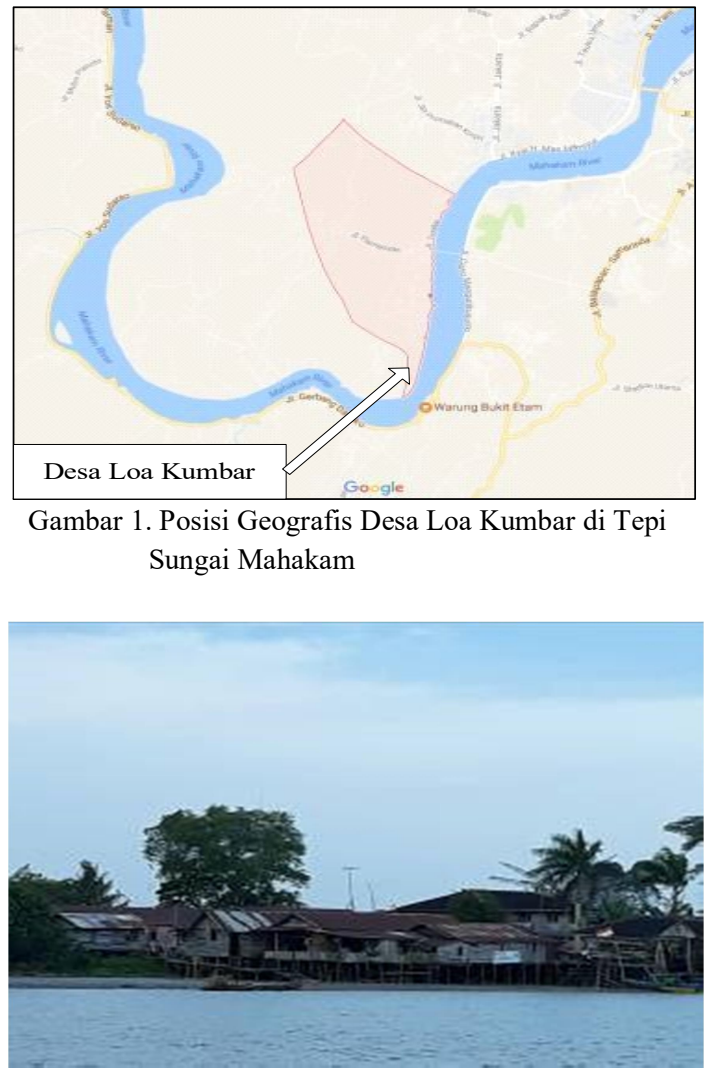

Gambar 2. Tampak Depan Desa Loa Kumbar di Tepi Sungai Mahakam

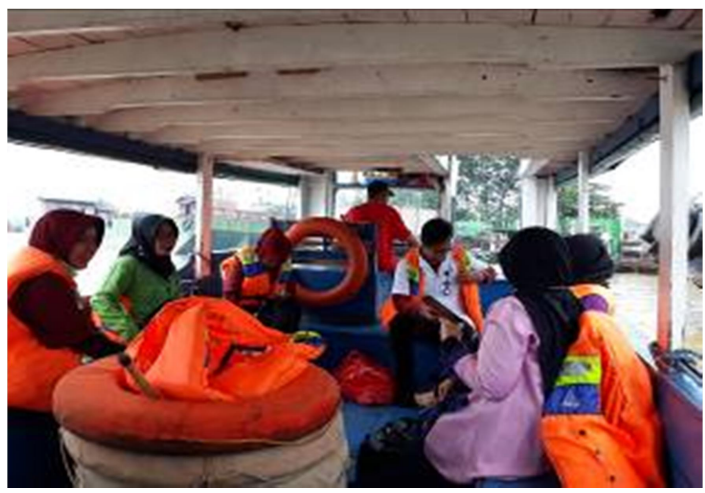

Gambar 3. Perjalanan Sungai Menuju Desa Loa Kumbar

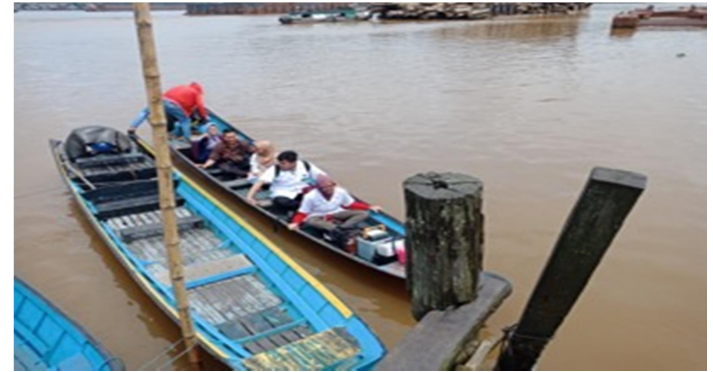

Gambar 4. Perjalanan Menuju Desa Loa Kumbar Menggunakan Kapal Kecil

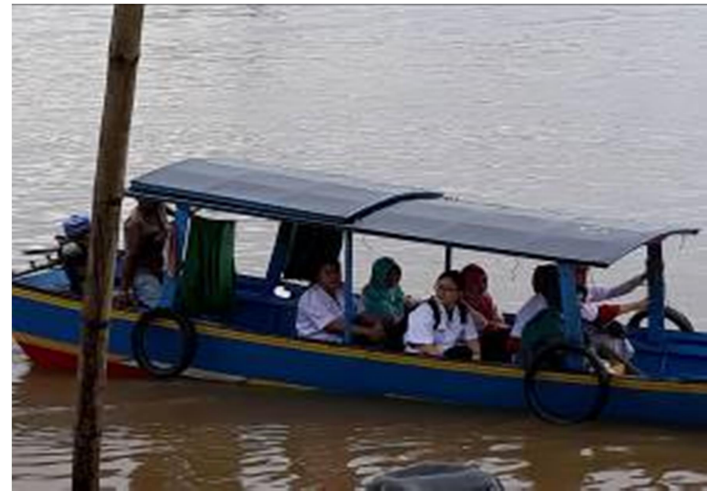

Gambar 5. Perjalanan Menuju Desa Loa Kumbar Menggunakan Kapal Sedang

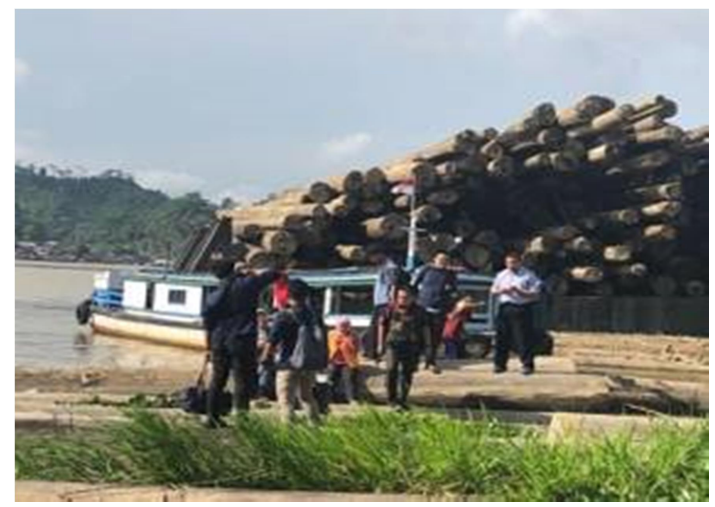

Gambar 6. Kapal Menuju Desa Loa Kumbar Berlabuh di Batang Kayu

\section{METODE}

Program Kemitraan Masyarakat ini merupakan program pemberdayaan masyarakat berupa optimalisasi Pos Pelayanan Terpadu (Posbindu) sebagai salah satu upaya penanggulangan Penyakit Tidak Menular (PTM). Posbindu PTM merupakan peran serta masyarakat dalam melakukan kegiatan deteksi dini dan pemantauan faktor risiko PTM utama yang 
dilaksanakan secara terpadu, rutin, dan periodik. Faktor risiko penyakit tidak menular (PTM) meliputi merokok, konsumsi minuman beralkohol, pola makan tidak sehat, kurang aktifitas fisik, obesitas, stres, hipertensi, hiperglikemi, hiperkolesterol serta menindak lanjuti secara dini faktor risiko yang ditemukan melalui konseling kesehatan dan segera merujuk ke fasilitas pelayanan kesehatan dasar (Kemenkes RI, 2012). Gambar 7 dan 8 menunjukkan Posbindu PTM di Desa Loa Kumbar.

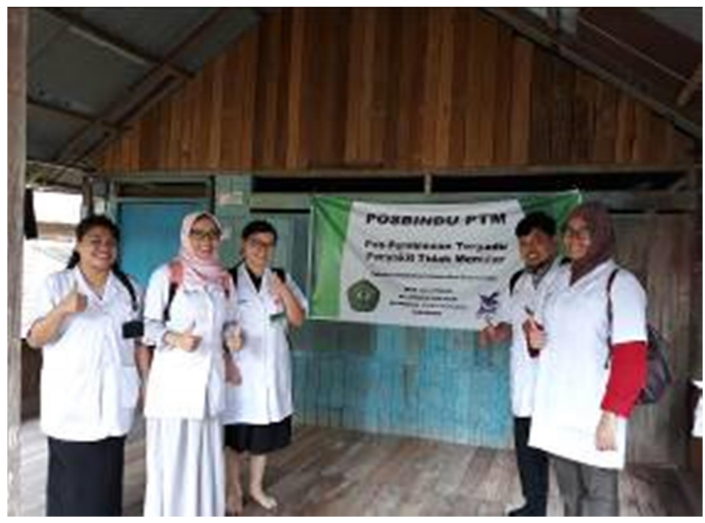

Gambar 7. Dokter Muda Fakultas Kedokteran Universitas Mulawarman di Depan Posbindu PTM Desa Loa Kumbar

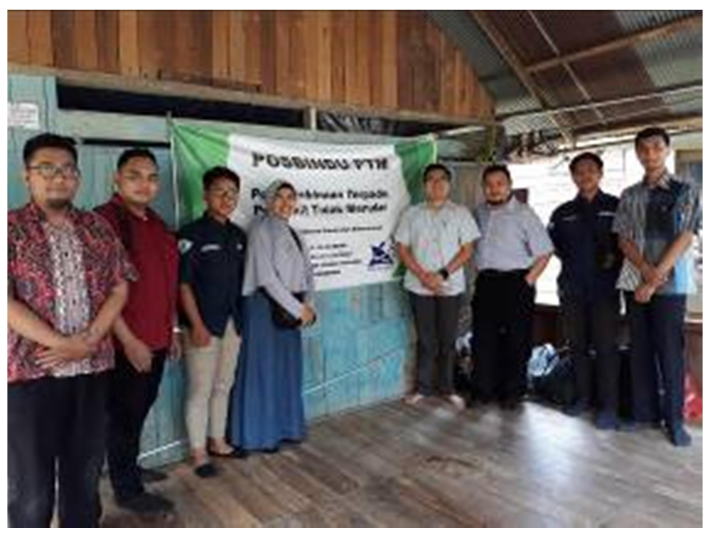

Gambar 8. Mahasiswa Fakultas Kedokteran Universitas Mulawarman di Depan Posbindu PTM Desa Loa Kumbar

\section{HASIL DAN PEMBAHASAN}

\subsection{Persiapan Kegiatan.}

Pada tahap persiapan dilakukan pengumpulan data yang akan diperlukan yaitu melalui metode berikut. Pengumpulan data sekunder dari Dinas Kesehatan Kota Samarinda dan Puskesmas Loa Bakung mengenai frekuensi PTM dan distribusinya secara kelompok usia, jenis kelamin, dan sebagainya. PTM yang dikumpulkan datanya sesuai dengan daftar kelompok PTM utama menurut Kemenkes RI (2012), yaitu diabetes melitus (DM), kanker, penyakit jantung dan pembuluh darah (PJPD), penyakit paru obstruktif kronis (PPOK), dan gangguan akibat kecelakaan dan tindak kekerasan.

Diskusi dengan tenaga kesehatan Puskesmas Loa Bakung mengenai faktorfaktor yang mempengaruhi masalah dan upaya penanggulangan PTM di Desa Loa Kumbar, serta faktor-faktor dari masyarakat dan lingkungan geografis yang dapat menghambat dan mendorong optimalisasi Posbindu PTM.

Diskusi dengan tokoh masyarakat, mulai dari Desa Loa Kumbar hingga Kecamatan Sungai Kunjang, mengenai faktor-faktor dari masyarakat dan lingkungan geografis yang dapat menghambat dan mendorong upaya kesehatan berbasis masyarakat terkait PTM termasuk optimalisasi Posbindu PTM. Gambar 9 menunjukkan peta Desa Loa Kumbar dan Gambar 10 adalah aula Desa Loa Kumbar tempat pelaksanaan kegiatan program.

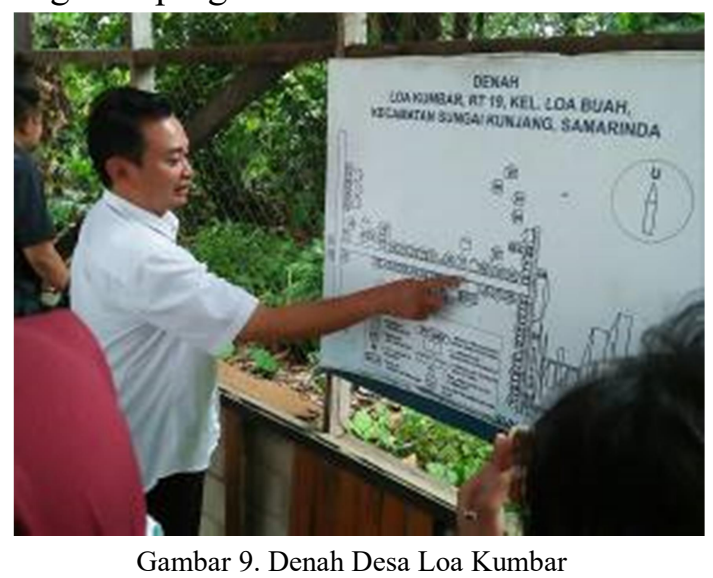




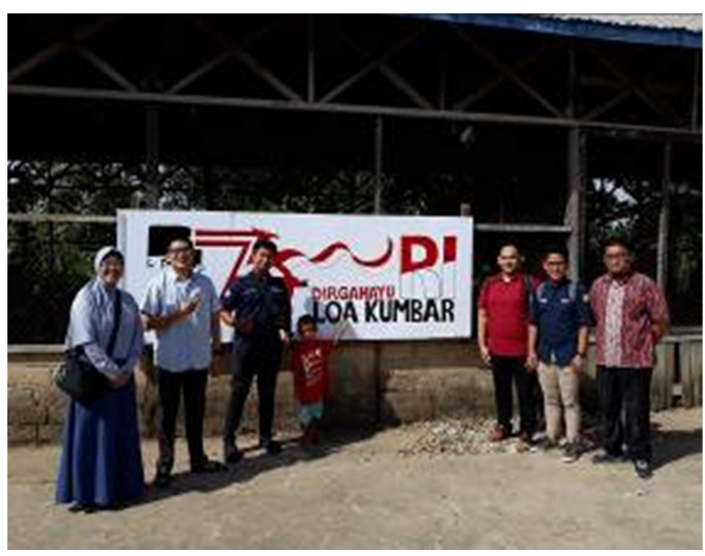

Gambar 10. Aula Desa Loa Kumbar

\subsection{Pelaksanaan Kegiatan.}

Kegiatan ini dilakukan di Desa Loa Kumbar dan Puskesmas Loa Bakung, Kecamatan Sungai Kunjang, Kota Samarinda. Kegiatan ini direncanakan untuk satu tahun anggaran. Lama waktu pelaksanaan kegiatan adalah dua belas bulan setelah proposal disetujui. Pelaksanaan kegiatan meliputi sebagai berikut.

Sosialisasi dan diskusi dengan masyarakat Desa Loa Kumbar untuk pembentukan Posbindu PTM. Masyarakat akan dilibatkan secara penuh di dalam pembentukan Posbindu PTM. Sosialisasi program akan dilaksanakan secara bertahap yaitu di Puskesmas Loa Bakung selaku pihak yang akan berkaitan erat dengan kegiatan Posbindu PTM, kemudian sosialisasi kepada masyakarat Desa Loa Kumbar melalui perangkat desa. Selanjutnya perangkat desa dapat menyebarkan informasi ke seluruh masyarakat Desa Loa Kumbar, harapannya masyarakat dapat berkomitmen dalam melaksanakan program Posbindu PTM.

Pembentukan Posbindu PTM dan kader Posbindu PTM. Seluruh kegiatan Posbindu PTM Desa Loa Kumbar akan berada dibawah pengawasan Puskesmas Loa Bakung. Selanjutnya yang disebut dengan kader adalah warga Desa Loa Kumbar
(Halaman 1-9)

yang akan dilatih oleh Puskesmas Loa Bakung dalam upaya penanggulangan PTM dan bersedia bekerja secara sukarela. Sebagian besar kegiatan Posbindu PTM akan bertumpu pada peran serta dan tugas kader.

Pelatihan kader Posbindu PTM. Kaderkader Posbindu PTM akan diberikan pelatihan sebelum menjalankan peran serta dan tugasnya. Pelatihan kader dilaksanakan oleh Fakultas Kedokteran Universitas Mulawarman, bekerja sama dengan Puskesmas Loa Bakung dan Dinas Kesehatan Kota Samarinda. Tujuan pelatihan ini adalah meningkatkan pengetahuan dan keterampilan kader dalam mengelola Posbindu PTM. Kader akan diberikan buku panduan Posbindu PTM, formulir-formulir pelaporan (kartu menuju sehat [KMS] faktor risiko PTM [FR-PTM] dan buku pencatatan hasil kegiatan Posbindu PTM), dan lembar balik sebagai media penyuluhan PTM.

Pelaksanaan kegiatan Posbindu PTM. Untuk standar minimal Posbindu PTM terdiri dari lima set meja dan kursi, pengukur tinggi badan, timbangan berat badan, pita pengukur lingkar perut, dan tensimeter serta buku pintar kader tentang cara pengukuran tinggi badan dan berat badan, pengukuran lingkar perut, alat ukur analisa lemak tubuh dan pengukuran tekanan darah dengan ukuran manset dewasa dan anak, alat uji fungsi paru sederhana (peakflowmeter) dan media bantu edukasi. Untuk standar lengkap diperlukan tambahan alat ukur kadar gula darah dan alat ukur kadar kolesterol total. Untuk pelaksanaan pencatatan hasil pelaksanaan Posbindu PTM diperlukan kartu menuju sehat Faktor Risiko Penyakit Tidak Menular (KMS FR-PTM) dan buku pencatatan. Untuk mendukung kegiatan edukasi dan konseling diperlukan media 
KIE (Komunikasi, Informasi dan Edukasi) yang memadai, seperti serial buku pintar kader, lembar balik, leaflet, brosur, model makanan (food model) dan lainnya. Gambar 11 hingga Gambar 14 menunjukkan kegiatan Posbindu PTM di Desa Loa Kumbar.

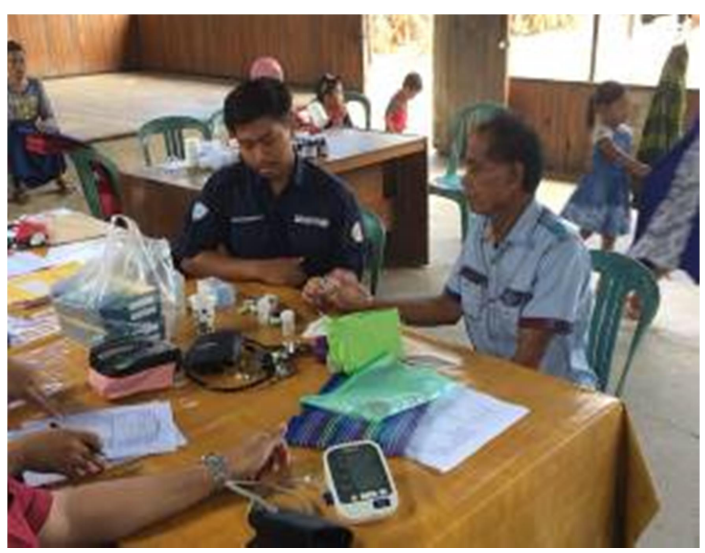

Gambar 11. Pelaksanaan Posbindu PTM di Desa Loa Kumbar

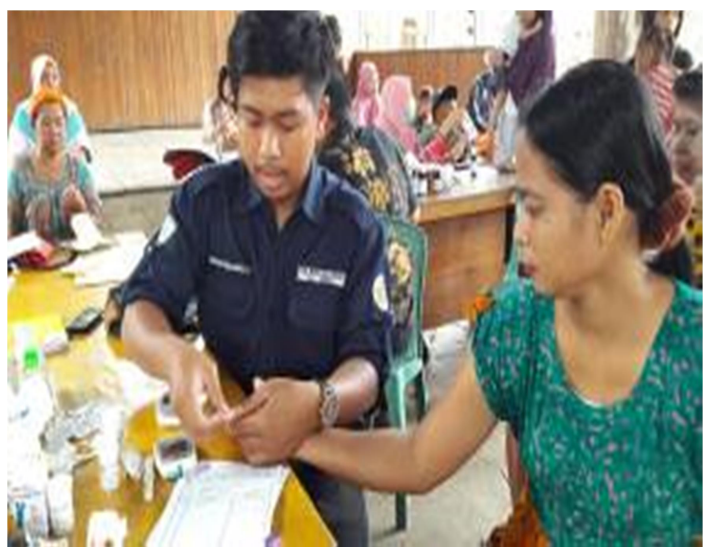

Gambar 12. Pemeriksaan Kadar Gula Darah Sewaktu

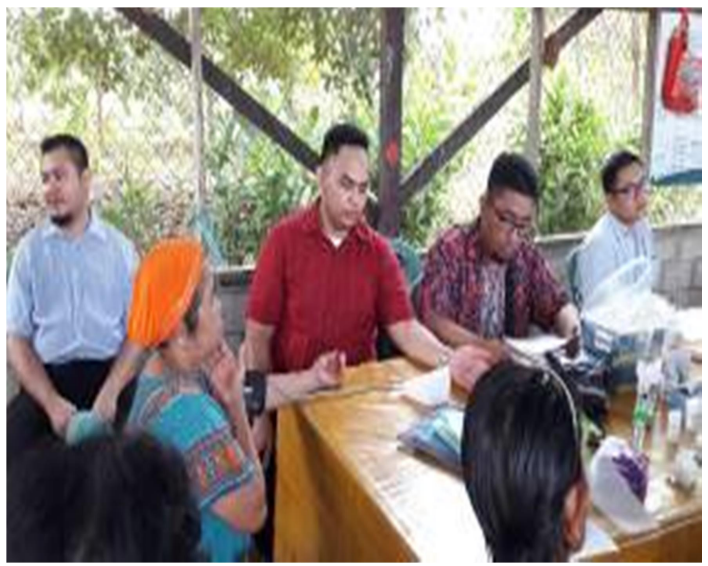

Gambar 13. Pemeriksaan Tekanan Darah

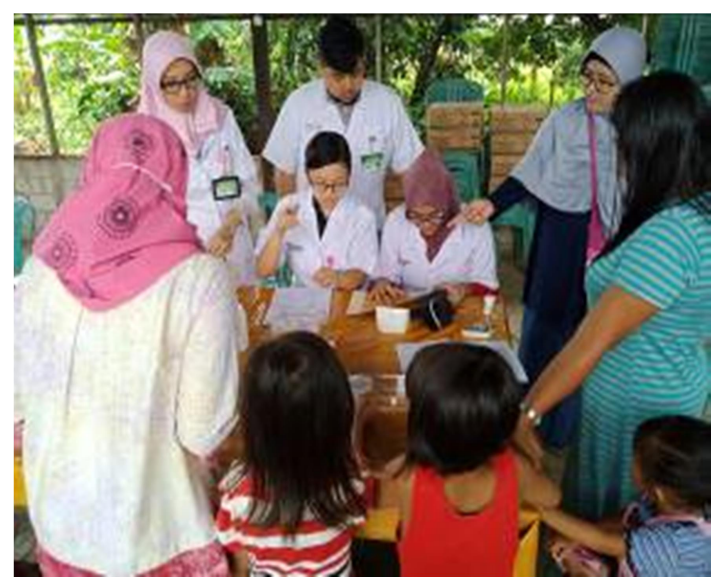

Gambar 14. Pelaksanaan Kegiatan Posbindu PTM di Desa Loa Kumbar

\subsection{Partisipasi Mitra.}

Di bawah pengawasan Dinas Kesehatan Kota Samarinda, Puskesmas Loa Bakung berkontribusi dalam hal memulai optimalisasi Posbindu PTM melalui sosialisasi program, merekrut dan melatih kader Posbindu PTM, memonitor dan mengevaluasi kinerja kader, serta melakukan pelaporan ke Dinas Kesehatan Kota Samarinda terkait kegiatan Posbindu PTM.

Masyarakat Desa Loa Kumbar dilibatkan penuh untuk mendukung program optimalisasi Posbindu PTM ini yaitu:

1) Menyumbangkan tenaga kader Posbindu PTM yang akan menjadi ujung tombak kegiatan penanggulangan PTM,

2) Peningkatan kesadaran untuk pencegahan PTM bagi diri sendiri, masyarakat dan lingkungan.

\subsection{Monitoring dan Evaluasi.}

Seluruh kegiatan Posbindu PTM akan dimonitor oleh Puskesmas Loa Bakung dan dilakukan evaluasi program. Puskesmas Loa Bakung memberikan lembar pelaporan kasus kepada kader untuk diisi dan dikumpulkan kembali 
kepada Puskesmas Loa Bakung setiap bulannya. Lembar pelaporan tersebut menjadi salah satu media monitoring kegiatan Posbindu PTM. Setiap tiga bulan sekali, kader akan dikumpulkan di Puskesmas Loa Bakung dan dilakukan evaluasi kegiatan Posbindu PTM dan adanya penambahan ilmu jika diperlukan.

Demi mewujudkan Posbindu PTM yang mandiri dan berkelanjutan, sangat diperlukan komitmen masyarakat Desa Loa Kumbar, kader Posbindu PTM, Puskesmas Loa Bakung, dan Dinas Kesehatan Kota Samarinda dalam pelaksanaan kegiatan Posbindu PTM. Adapun monitoring dan evaluasi program secara keseluruhan akan dilakukan oleh tim dari Fakultas Kedokteran Universitas Mulawarman, LP2M Universitas Mulawarman dan Dinas Kesehatan Kota Samarinda.

\subsection{Keberlanjutan Program.}

Dengan dilaksanakannya program kemitraan masyarakat ini diharapkan masyarakat di Desa Loa Kumbar, Kecamatan Sungai Kunjang, dapat menjadi mandiri dalam penanggulangan PTM, dan selanjutnya dapat menjadi contoh bagi pengembangan di kabupaten atau kota lain di Kalimantan Timur, yang juga sering terkendala masalah geografis serupa. Selain itu diharapkan pula setelah program ini selesai dapat terbentuk jaringan yang saling mendukung antara Dinas Kesehatan Kota Samarinda, Fakultas Kedokteran Universitas Mulawarman dan mitra lain yang berkepentingan untuk penanggulangan PTM. Kader-kader yang sudah dilatih dan partisipasi aktif dari masyarakat diharapkan dapat meneruskan kegiatankegiatan penanggulangan PTM yang berkelanjutan.

\section{PENUTUP}

Hasil program yang telah dilakukan adalah mitra dalam hal ini pihak Puskesmas telah memulai pembentukan Posbindu PTM serta melakukan pelaporan ke Dinas Kesehatan Kota Samarinda terkait kegiatan Posbindu PTM. Luaran pengabdian masyarakat yang telah tercapai adalah telah mulai dilakukan penerapan iptek kepada masyarakat, terutama penggunaan alat kesehatan untuk skrining faktor risiko penyakit tidak menular, khususnya tekanan darah tinggi dan kencing manis.

\section{UCAPAN TERIMAKASIH}

Ucapan terima kasih kepada Direktorat Riset dan Pengabdian Masyarakat, Direktorat Jenderal Riset dan Pengembangan, Kementerian Riset, Teknologi dan Pendidikan Tinggi, Republik Indonesia, atas pembiayaan program pengabdian masyarakat ini melalui skema Program Kemitraan Masyarakat (PKM) tahun 2018.

\section{DAFTAR RUJUKAN}

Badan Pusat Statistik. (2017). Data Badan Pusat Statistik Kota Samarinda Tahun 2015. Badan Pusat Statistik. Samarinda. Diakses dari http://www.samarindakota.bps.go.id.

Ernawati S. (2016, 17 Mei). Daerah Terisolir Bangkit Dengan Perilaku Hidup Sehat. Kompasiana. Diakses dari http://www.kompasiana.com.

Kementerian Kesehatan RI. (2008). Riset Kesehatan Dasar Tahun 2007. Badan Penelitian dan Pengembangan Kesehatan. Kementerian Kesehatan RI. Jakarta. 
Kementerian Kesehatan RI. (2012). Petunjuk Teknis Pos Pembinaan Terpadu Penyakit Tidak Menular (POSBINDU PTM). Direktorat Jenderal Pengendalian Penyakit dan Penyehatan Lingkungan. Direktorat Pengendalian Penyakit Tidak Menular Kementerian Kesehatan RI. Jakarta.

Kementerian Kesehatan RI. (2013). Riset Kesehatan Dasar Tahun 2013. Badan Penelitian dan Pengembangan Kesehatan. 72-77. Kementerian Kesehatan RI. Jakarta.

Lembaga Penelitian dan Pengabdian Masyarakat (LP2M) Universitas Mulawarman. (2016). Rencana Strategis 2016-2020. Universitas Mulawarman. Universitas Mulawarman.

Pardede DA. (2014, 7 Oktober). Akses Darat Loa Kumbar Samarinda Akhirnya Tersambung. Tribun Kaltim. Diakses dari http://www.kaltim.tribunnews.com.
Pardede DA. (2015, 25 November). Titik Terjauh Pelaksanaan Pilkada ada di Desa Loa Kumbar. Tribun Kaltim. Diakses dari http://www.kaltim.tribunnews.com.

Pemerintah Kota Samarinda. (2017). Data Kecamatan Pemerintah Kota Samarinda. Diakses dari http://www.samarindakota.go.id.

Pitakasari AR. (2011, 16 Mei). Duh. Sudah 65 Tahun Merdeka, Masih Ada Pemukiman Terisolir di Samarinda. Republika. Diakses dari http://www.republika.co.id.

Puskesmas Loa Bakung. (2016). Profil Puskesmas Loa Bakung Tahun 2016. Dinas Kesehatan Kota Samarinda. Samarinda.

Setiawan D. (2013). Pelaksanaan CSR di Kota Samarinda: Studi Tentang Tanggung Jawab Sosial Perusahaan (CSR) PT Transisi Energy Satunama di Kelurahan Loa Buah dan Kelurahan Lok Bahu. eJournal Ilmu Pemerintahan. 1(1): 359-373. 
